\title{
Income inequality, Redistribution, and Democracy
}

\author{
Linda de Jongh \\ Supervisor: Prof. K. Thomsson
}

Many economists, and more generally institutions are concerned with the development of poor countries. Not only poverty, but also income inequality can have perverse consequences on the economic, political, and social stability of a country. In order to get more insight into this topic the main research question was: How is income inequality determined by regime type and is there a difference in the way democracies and dictatorships redistribute income?

To answer this question we used a sample consisting of an unbalanced panel of 104 countries and 924 observations for which data was available between 1990 and 2006. The two main variables of interest in this analysis are inequality and democracy. The measure for income inequality is the Gini index, taken from the World Income Inequality Database 2 (WIID2) (UNU-WIDER, 2008b). The second important variable in this analysis is democracy. A good indication of the democracy of a country is measured by the polity score. It seems to be that there is, at least between polity scores -10 and 8 a positive relationship between inequality and democracy for non-communist countries. However, two observations are less clear. On the one hand, it is less clear whether inequality will decrease once a country moves beyond polity score of 8 . On the other hand, it is less clear whether inequality increases with the same speed, irrespective of how autocratic a country is or whether an increase in democracy in a very autocratic country leads to a higher increase in inequality than the same increase in democracy for a more democratic country. Second, for (post) communist countries, the relationship is different. The increase in inequality when an autocratic country becomes more democratic is less steep than for non-communist countries and second, inequality starts to fall much earlier and much more when a (post) communist country moves beyond a polity score of 1 .

We can find three individual processes in democratization: democratization of the recruitment of the executive, the degree of independence of the executive authority, and the degree of political competition and opposition. The democratization of executive recruitment leads to a linear, negative effect on inequality, while the degree of political competition leads to a linear, positive effect on inequality. If a (post)communist country experiences an increase in the independence of executive authority, inequality increases 
to a lesser degree than for a non-communist country. Additionally, the level of inequality starts to fall sooner for a (post)communist country as compared with a non-communist country when the degree of independence increases. It is concluded that democracy not only leads to more inequality, it also leads to less redistribution.

\section{Introduction}

Many economists, and more generally institutions such as the World Bank, International Monetary Fund (IMF), and the United Nations (UN), are concerned with the development of poor countries. Today, one out of every six people lives in poverty (Perkins, Radelet, \& Lindauer, 2006, p. 189). This indicates that the topic of development is an important one and should be on the political agenda of many countries across the globe. Income inequality can have perverse consequences on the economic, political, and social stability of a country. Pickett and Wilkinson, as cited in Fukuyama (2012a, p. 7), conclude that there is a correlation between a high level of income inequality and many social ills such as drug use, obesity, criminality, and poor educational performance. In today's world we witness the concequences of ethnic conflicts. According to Collier, as cited in Fukuyama (2012a, p. 8), these ethnic conflicts are a result of an unequal distribution of wealth in these countries. Inequality can lead to reduced economic growth because of several reasons: access to credit may be unequal (Fukuyama, 2012a, p. 8); since wealthy citizens can afford to pay privatly for public goods, the demand for these goods can be low and therefore not provided to everyone in a highly unequal country (Birdsall, as cited in Fukuyama, 2012a, p. 8). The most straightforward reason why high inequality undermines economic growth is the resulting social conflict between the rich and the poor (Fukuyama, 2012a, p. 8). High inequality has also a negative effect on democratic quality. According to Solt, as cited in Bermeo (2012, p. 18), there is a strong relation between high levels of income inequality and reduced political interest. Additionally, inequality gives rise to populism, humanrights abuses, and the acceptance of authoritarism (Przeworski, as cited in Bermeo, 2012, 18). From this discussion it is clear that inequality has negative concequences for a country. However, why is income distributed differently in different countries?

According to Simpson (1990) there are three general views on the determinants of income inequality. First, the economic view follows the idea of the Kuznets's curve: when a country starts to develop income inequality rises and after a certain threshold inequality declines again. The second view is a political model. Instead of the income per capita being the determinant of income inequality, political factors are the determinants of income 
inequality. The third view looks at the theories of the world-system. According to this view, the level of inequality in a country is determined by its position in the world economic order. However, there has not been found any statistical evidence for this view. This paper will dig deeper into the second view of determinants of income inequality. More specific, it will look at how regime type determines income inequality.

Looking at the literature about income inequality and regime type, two major approaches in the literature can be observed. First, some literature looks at how income inequality determines whether a country will go into transition to democracy, and second, some literature looks at how democracy or regime type determines income inequality within a country. These two approaches basically look at the reverse causality of each other. This paper will look into the causality running from regime type to income inequality. The main question to be answered in this paper is: how is income inequality determined by regime type and is there a difference in the way democracies and dictatorships redistribute income? This paper is divided in six sections. The next section, section 2, will explain the theoretical arguments and empirical proofs of the relationship between democracy and inequality. Section 3 will describe the data and methodology used in this paper, and section 4 will explain the results. In this section, both no-effects and fixed effects regressions are used to find the interaction between inequality and polity type. Additionally, there will be looked in more detail at the individual processes of democracy and how they, each separately, affect inequality. Third, in a final regression, the relationship between redistribution and regime type is reported. The last section concludes, reports the main findings and lays out possibilities for further research. All tables and figures are given in the appendix.

\section{Democracy and income inequality}

\subsection{Theoretical arguments}

Looking at the theoretical relationship between democracy and income inequality, there are theorists who believe that democracy leads to higher inequality and theorists who believe that income equality is intrinsic to democracy. Liberal theorist Friederich Hayek finds that a democracy should entail and needs to accept higher degrees of inequality. For example, he finds the progressive income tax illegitimate since the government uses power over individuals, which runs counter to the definition of democracy (Fukuyama, 2012a, p. 5). Theorists who believe that democracy is linked with equality can be divided into neoliberals and liberals. As a neoliberal, Karl Marx argues that the outcome of democratic elections is determined by the bourgeoisie and does not reflect the true 
interest of all people. The solution, according to Marx, is to have an authoritarian regime that speaks in the 'name of the people' (Fukuyama, 2012a, pp. 5-6). Liberal theorists, such as John Rawls and Amertya Sen, argue that in a democracy there is a certain ethical rule that there should be some equality, even if this runs counter to the strict idea of a free society. For example, Sen argues that actual freedom can only be achieved when there are certain material preconditions such as enough food and good health. If this is not the case, then Hayekian freedom from government intervention will not be sufficient for individuals to make good choices. A liberal society should provide these preconditions, and this requires a certain amount of redistribution (Fukuyama, 2012a, p. 6). In the twentieth century, to the right for freedom, which entails democracy, came a form of 'second-generation' rights, such as rights to education, health, and housing which require some form of redistribution in most countries (Fukuyama, 2012a, p. 6). Already since Aristotle there is the belief that democracy works best when extremes of wealth and poverty are reduced. However, it is antithetical to the belief of democracy that the government has the right to fully determine the distribution of income (Plattner, 2012). Acemoglu and Robinson, as cited in Bermeo (2012), also believe that democracy leads to less inequality. According to them, 'democracy is pro-majority and even possibly pro-poor' (p. 17). According to Toledo (2012, p. 42), democracy is on the one hand an egalitarian system because everyone is a shareholder in the system. However, Toledo also recognizes that democracy works best in a market economy which carries the cost of producing income inequalities. This discussion shows that upfront it is unclear whether democracy leads to more or less inequality. Since theory fails to determine whether democracy leads to more or less inequality, we must look at the empirical evidence in the next section to find the answer.

\subsection{Empirical evidence}

In addition to the theoretical arguments outlined above, there is a lot of empirical literature looking at the relationship between democracy and inequality. This section will start by briefly examining some literature that looks at the causality running from income inequality to regime type. In his paper, Muller (1988) has two hypotheses: the genesis hypothesis is stating that a precondition for democracy is an egalitarian distribution of income, the stability hypothesis is stating that once a democracy has been established, equal income distribution increases regime stability. For the genesis hypothesis, Muller (1988) finds no empirical evidence. However, he finds a strong relation between high levels of income inequality and the likelihood of a breakdown of democracy. Dutt and Mitra (2008) also look at the causality running from income inequality to regime type. More specifically, they look at how income inequality leads to political instability which leads to trade and government spending volatility. This in turn leads to output 
volatility, low investments and weak growth. Their measure of political instability only reflects movements from dictatorship to democracy and vice versa, but does not capture movements within a democratic or authoritarian government. Their results find evidence that unequal countries move in and out of democracy more often than equal societies. Concluding, there is some evidence that income inequality determines regime type. In an extensive analysis, Boix (2003) reaches the same conclusion: lower levels of inequality, together with less specific assets, increases both the probability of a transition towards democracy and the stability of these regimes. Kapstein and Converse (2012) reach the same conclusion. They find that initial conditions, such as high levels of inequality, negatively affect the survival of democratic regimes. Reenock, Bernhard and Sobek, as cited in Bermeo (2012, p. 24), reach a slightly different conclusion. They find that the durability of democracy in developing countries was threatened most by basic needs shortfalls, rather than by inequality. Overall, there is a strong indication that indeed high levels of income inequality negatively influence the change of democracy and its stability.

Turning to the causality of interest, going from regime type to income inequality, Gradstein \& Milanovic (2004) give an overview of the history of this research literature. According to them, the research in this topic in the 1960 s and 1970 scould not find any statistical relationships between regime type and income inequality, but made clear some methodological issues. Examples of these methodological issues are measurement errors, sample composition, and model specification. However, nowadays measurement of income inequality and regime type has become significantly better. Additionally, because recently there is more data available compared with the 1960s, studies done in the $1990 \mathrm{~s}$ seem to be more conclusive. The research conducted in the 1990 shows a negative relationship between democracy and inequality. Some authors find even an inverted U-relationship: inequality is lowest at very autocratic and very democratic governments, but high in countries that are between the two extremes.

Muller (1988) uses panel data for the period 1965-1975, excluding centrally-planned economies, and finds a significant negative relation between years of democracy and inequality. Moreover, he finds evidency for the Kuznets's curve. Simpson (1990) uses panel data of 62 countries in the period between 1962-1975. As the measure of inequality he uses both the Gini index and the percentage of income received by the top quintile. As the measure of regime type, he uses Bollen's political democracy index. Simpson (1990) concludes that there is a significant U-shaped relationship between inequality and democracy, using both dependent variables. Besides democracy being a predictor of inequaliy, the general educational level was also a good predictor. Economic development, measured by gross national income (GNI) and the world-system variables were both insignificant. 


\section{Data and methodology}

As the above section has explained, there is no clear relationship between income inequality and regime type. Theoretically, there are different views on whether a democracy should lead to more or less inequality than an autocracy. Empirically, there are also several different views. Muller (1988) found a negative relationship between inequality while Simpson (1990) concluded that inequality rises when a country becomes more democratic but after a certain threshold inequality would decrease again.

Because theoretical arguments fail to provide an answer, the question whether democratization leads to higher or lower inequality ultimately needs to be answered empirically. However, since several empirical analyses are showing different answers, there must be an improvement on the empirical analysis. This paper will make several improvements. First, by using fixed effects regression next to the often used OLS- or no effects regressions it can improve the robustness of the analysis. Fixed effects regressions make use of panel data and are an improvement to OLS- or no-effects regression when one thinks each cross-section, a country in this case, has a separate intercept (Kennedy, 2008, p. 283). In this case, it might be that each country has its separate intercept. For example, one can think of a variable such as political ideology to have an influence on inequality. These country-specific fixed effects dummies can control for ideology. Second, income inequality data is often of poor quality, definitely when one has to compare between several countries. There is no standard of how to measure inequality and every country and data source use different methods to calculate inequality. By controlling for the most significant differences, one can find a more trustful relationship between inequality and democracy. Third, by including more and different controls than in other empirical analysis, one can find more insight in the real relationship between inequality and democracy.

\subsection{Dependent variable}

The primary sample consists of an unbalanced panel of 104 countries and 924 observations for which data was available between 1990 and 2006. The two main variables of interest in this analysis are inequality and democracy. The measure for income inequality is the Gini index, taken from the World Income Inequality Database 2 (WIID2) (UNU-WIDER, 2008b). UNU-WIDER has constructed this dataset out of several different datasets that reported the Gini index for a certain country and year. In many cases UNU-WIDER has recalculated the Gini index so that it was better comparable. However, it is very hard to compare Gini indexes across countries and different dataset. UNU-WIDER reports together with the Gini index, how that Gini index is calculated (UNU-WIDER, 2008a). For 
many countries there has been several different Gini indexes reported for the same year. Some of the guidelines that are followed to choose a single Gini index are the following: first, the Gini should have been calculated over a larger part of the population. Second, it was preferred to have a broad income definition. Inequality was not only measured over earnings from employment, but over monetary income and nonmonetary income. Further it was preferred to have inequality measured over disposable income, after taxes and transfers has been deducted and added. Third, the quality of the Gini index, which was also reported in the dataset, should have been as high as possible. Fourth, for each country it was preferred to use a limited amount of data sources. This way, one can reduce the problems with different measurements within one country.

\subsection{Independent and control variables}

The second important variable in this analysis is democracy. A good indication of the democracy of a country is measured by the polity score. This score is a number between -10 and 10, with -10 indicating a fully autocracy and 10 a fully democracy. The polity scores are taken from the polity IV dataset provided by the Center for Systemic Peace (Gurr \& Marshall, 2012). The polity score is calculated from three different characteristics of a democracy: the degree of executive recruitment, the degree of independence of executive authority, and the degree of political competition and opposition (Gurr, Jaggers, \& Marshall, 2010).

The main control variables chosen for this analysis are the logarithm of GNI per capita, the logarithm of energy use per capita, secondary school enrollment, age dependency ratio, employment in agriculture, service sector, and tax revenue. These data are all taken from the World dataBank (World Bank, n.d.). GNI per capita controls for economic development. As explained in the introduction, one view on the determinants of inequality is economic development. According to the Kuznet's curve, inequality rises when a country starts to develop and falls again after a certain threshold of development. Additionally, to control for this curvature relationship between economic development and inequality, a squared term of GNI per capita is added. Energy use per capita is also a control for economic development (Muller, 1988). The third view on the determinants of inequality, that a country's position in the world order affects its inequality level has not been found significant in both Muller (1988) and Simpson (1990). Therefore, this is left out of this analysis. The school enrollment rate is a control for the general educational level in a country. It might be expected that when the educational level goes up in a country, inequality goes down, but that this effect is weaker the higher the educational level. Therefore, a squared term of education is added. The age dependency ratio is the sum of the population 15 years of age or younger and 65 years of age or older as a percentage 
of the working-age population. When this ratio is large, it means that few people in the working-age have to provide services for a large part of the population who are not in the working-age. Therefore, it is expected that age dependency is positively related with inequality. Both employment in agriculture and the service sector control for the type of economy in a specific country. If the country is more based on agriculture, employment in agriculture is expected to be higher and if a country is more based on services, services as a percentage of gross domestic product (GDP) is obviously higher. Tax revenue is measured as the government tax revenue as a percentage of GDP. Tax revenue is expected to be negatively related with inequality because if the government has more revenue it can also use more of these resources to redistribute and therefore inequality is lower.

To control for the largest differences in the measurement of the Gini, seven controls are added for the type of income definition used. Urban is a dummy variable that has a value of 1 when the Gini is measured on incomes from only citizens living in urban areas. The two dummies gross and disposable control for whether Gini is measured on income before or after tax. Consumption and earnings are two dummies to control for the type of income used to calculate Gini. Consumption has a value of 1 when Gini is calculated over the consumption of individuals and households. In general, consumption is more equally distributed than income (Deaton \& Zaidi, as cited in Gurr, Jaggers, \& Marshall, 2010, p. 4). Earnings has a value of 1 when only income from employment and self-employment are used. The dummy shareuhousehold stands for that the income sharing unit used to calculate Gini is households, family, or tax unit, as opposed to person. A household needs relatively less income than a person to achieve the same amount of wealth because of economies of scale. The last control is uofanalaperson, which stands for that the unit of analysis is a person. In this case the Gini is adjusted to the person rather than the household. It is expected that when the unit of analysis is a person, inequality is higher than when inequality is compared across households.

\subsection{Missing data}

Since there are in several series data missing, linear interpolation is used for the following variables: Gini, energy, education, agriculture, service, and tax. In the case of Gini data, if the raw data had a gap of more than ten years, no interpolation was used. If the gap between two data points was less than ten years, linear interpolation was used. According to Muller (1988, p. 53), measurements of income inequality across years are comparable if the gap is not more than eleven years. 


\section{Results}

\subsection{Panel Least Square regression analyses}

Table 1 shows the results of models 1 through 7 . All these models are Panel Least Squares (PLS) regressions with Gini as the dependent variable and the $p$-values are calculated using White period standard errors. Model 1 analyses the effect of polity on Gini. The coefficient of polity is negative, but insignificant. The coefficients on the controls for the measurement of Gini are significant in 6 out of 7 times. To control for a curvature relationship between inequality and democracy, a square of the polity variable is added in model 2 . Now, both polity and polity ${ }^{2}$ are significant at the 10 percent level. According to model 2 , there is an inverted $\mathrm{U}$-shaped relationship between inequality and democracy, with its maximum around a polity score of 1 .

Model 3 adds the controls as described in section 3.2. In addition, there is also an interaction term added between tax and polity. That a government has more tax revenue than another government might indicate that it will redistribute more and inequality is lower. However, this is not necessarily the case. A government might also use this higher tax revenue to finance wars or other non-redistributive goods. It is expected that a democratic government is willing to use their tax revenues in a more redistributive manner than a more autocratic government. Comparing model 3 with model 2 , the change in the coefficient of polity is not much and the effect of polity ${ }^{2}$ is smaller, but both are still significant, at least at a 10 percent level. In model 3, there is clear evidence for the Kuznets's curve: there is an inverted U-shaped relationship between inequality and economic development and both terms of $\log (\mathrm{GNI})$ are significant at the 1 percent level. Additionally, $\log$ (energy) has a highly significant negative effect on inequality. It seems that the level of education has no effect on inequality: both terms are insignificant. Running the same regression without education ${ }^{2}$ does not influence the results. Also dependency, service, tax, and the interaction between tax and polity are insignificant. If the economy is more relying on agriculture, inequality is slightly higher, but this result is only significant at the 10 percent level.

To control for region-specific factors, model 4 adds three more dummies: Latin America, Africa, and Asia. As can be seen, Latin American countries have on average a Gini index which is 16.878 higher and for African countries this is 13.463 higher. Both the coefficients of Latin America and Africa are significant at the 1 percent level. Asian countries have a slightly higher Gini, however, this is not significant. The coefficient of polity is nearly the same as in model 3 , both the size and the significance, but the coefficient of polity ${ }^{2}$ becomes insignificant. Further, the other control variables are all insignificant, including 
economic development, with the exception of agriculture and the interaction between tax and polity. Model 4 indicates that region-specific variables explain most of the variance in inequality and that there is a positive relationship between inequality and democracy.

It is thinkable that (post)communist countries have on average a lower level of inequality. An Anova test for mean equality of Gini against whether a country is communistic or not. The data for this test are taken also from before 1990 to have a more robust test. On average non-communist countries have a Gini of 41.912 and communist countries 26.366 , which is substantially lower. This result is also significant at the 1 percent level. That (post)communist countries might have a different relationship between inequality and democracy than noncommunist countries is also recognized by Gradstein and Milanovic (2004). Even though the authors find a negative relationship between inequality and democracy for the rest of the world, they observe that after the fall of communism the (post)communist countries had an increase in both inequality and democracy. Moreover, together with the fact that Orenstein (2012, p. 79) concludes that people who lived in a communist country had expectations about the country's role in social policy, leads to the thought that, even if communism has already fallen, (post)communist countries might have a different relationship between inequality and democracy. Model 5 includes a dummy which has a value of 1 when the country had a communist government in 1980. Herewith, this analysis follows Brown (2009) which lays out a list of countries that were communist in 1980.' In model 5 communist and an interaction variable between communist and polity are added to control for both a different intercept and different slope between (post)communist and non-communist countries. As can be seen, communist countries have a higher level of inequality when the polity score would be at $\mathrm{o}$. This result is significant at the 5 percent level. However, when the level of democracy increases, the (post)communist country's level of inequeality increases less fast and also starts to decline earlier than non-communist countries. The effect that democratization has on inequality for non-communist and (post)communist countries has been graphed seperately in figure 1. Adding the two communist variables changes the coefficient of polity substantially. The coefficient increases to 1.95 and it is much more significant now. The coefficient of polity ${ }^{2}$ is also significant at the 1 percent level. Furthermore, in model $5 \log (\mathrm{GNI})$ and $\log (\mathrm{GNI})^{2}$ are again significant and show evidence for the Kuznet's curve. An agrarian

1 The list of these countries are Albania, Bulgaria, Cambodia, China, Cuba, Czechoslovakia (Czech Republic, Slovak Republic), East Germany, Hungary, Laos, Mongolia, North-Korea, Poland, Romania, Soviet Union (Armenia, Azerbaijan, Belarus, Estonia, Georgia, Kazakhstan, Kyrgyzstan, Latvia, Lithuania, Moldova, Russia, Tajikistan, Turkmenistan, Ukraine, Uzbekistan), Vietnam, Yugoslavia (Bosnia Herzegovina, Croatia, Kosovo, Macedonia, Montenegro, Serbia, Slovenia). 
economy has on average a higher level of inequality and the effects of the region-specific dummies of Latin America and Africa are still positive and significant at the 1 percent level. Asian countries have on average a lower level of inequality than European countries and this result is significant at the 10 percent level.

In figure 1 the results of model 5 are graphically represented. It can be seen that noncommunist countries have an almost always increasing relationship between inequality and democracy. What might explain this relationship? One possible answer is that it is not per se democracy that increases inequality, rather it is the market economy that is both positively correlated with inequality and democracy. According to Lewis (2012, p. 124), both systems of democracy and market economy rely on freedom of choice, open information, and decentralized decision making. As a proxy for the market economy, model 6 adds a dummy which has a value of 1 when in 2006 the country was member of the OECD. As can be seen in table 2, the coefficient of this dummy is insignificant and more importantly, it does not change anyting substantially at the polity coefficients and significance levels. If it would have been the case that a market economy actually leads to higher inequality rather than democracy, the polity coefficients would have turned insignificant after adding a dummy for OECD membership. A second option is to add other proxies for a market economy, such as trade and foreign direct investment (FDI). Trade is here the sum of exports and imports as a percentage of GDP and FDI is the net inflows as a percentage of GDP. Both data series are taken from the World dataBank (World Bank, n.d.). Nevertheless, model 7 shows that this has also no effect on the coefficients of the polity variables. Therefore, model 5 seems to be best predicting the relationship between inequality and democracy. However, we can improve on model 5. By using fixed effect regression instead of the no-effects regressions in table 2 , it is possible to control for country- and time-specific factors. This will be done in the next sub-section.

\subsection{Panel Least Square regression with fixed-effects}

Running model 5 in a random effects regression and using a Hausman test whether it is best to use a fixed effects regression or a random effects regression gives a Chi-Square statistic of 97.253 and with 20 degrees of freedom the $p$-value is less than 1 percent. This means that it is more legitimate to use fixed effects rather than random effects. Therefore, models 8 through 13 will use PLS fixed effects regressions with White period standard errors. In addition to cross-sectional fixed effects, all regression use period fixed effects. The results of these regressions can be seen in table 2. Model 8 regresses Gini on polity and the seven controls for the measurement of Gini. As was the case in model 1, polity is not significant and three out of seven Gini controls are significant. When the square of 
polity is added in model 9 , both polity coefficients stay insignificant. This is different than the result in model 2. Only when the other controls are added in model 10, polity becomes significant. However, polity ${ }^{2}$ stays insignificant. To see the actual effect of polity on Gini, model 11 replicates model 10, but leaves out the squared polity term. As can be seen, there is a positive effect of polity on Gini and this result is significant at the 1 percent level. Furthermore, the coefficients of economic development, agriculture, and service are all insignificant. The coefficient of dependency is positive and significant at the 10 percent level. This means that when the non-working aged population increases with respect to the working-age population, inequality goes up. This is what one would expect. The coefficient of tax and the interaction between tax and polity are both significant at the 1 percent level. Figure 2 shows graphically the effect of democracy on inequality for both a country with a low and a high level of tax revenue. A country with a high level of tax revenue has, ceteris paribus, a decreasing level of inequality when democracy increases. A country that has a low level of tax revenue has, ceteris paribus, an increasing level of inequality. One major drawback of using a fixed effects regression is that it is impossible to add time-constant variables to the regression because of perfect collinearity problems with the fixed effects dummies (Wooldridge, 2009). It is therefore not possible to replicate model 4 with the fixed effects regression. To control for communism, only the interaction term between communism and the polity score can be added, because communism itself is also a time-constant variable. As can be seen from model 12 in table 4, this interaction term is insignificant. This makes sense, because any effects which are specific to a country, such as communism, are already reflected in the country dummies of the fixed effects regression. Model 13 adds two variables to proxy for a market economy. Since OECD is a time-constant variable, this cannot be added to the fixed effects regression; therefore only trade and FDI are added in model 13 . As was the case in model 7 with the no-effects regression, trade and FDI are both insignificant. Additionally, the adjusted $\mathrm{R}^{2}$ is lower than was in model 11 and 12. From these fixed effects models, it seems that model 11 is best in predicting inequality. A redundant fixed effects test of model 11 to test for the joint significance of the cross-section dummies and the period dummies rejects the null hypothesis of no fixed effects.

Section 4.2 concluded that without fixed effects, model 5 seems to predict inequality best with an inverted $U$-shape as the relation between inequality and democracy. In section 4.3, model 11 with fixed effects seemed to predict inequality best. In this model, there is a positive relation between inequality and democracy. Are these two models really telling us a different story? Figure 3 shows in one graph the conclusions of model 5 and 11 , respectively, with respect to inequality and democracy. The graph is drawn using the constant and 
coefficients of polity and communism of both models 5 and 11. The curved lines show the results of model 5 , respectively for a non-communist and (post)communist country. The blue line shows the result of model 11. As already has explained, a major drawback of a fixed effects model is that no time-constant variables can be added. This means that, for example, no region-specific dummies can be added. However, this also means that when the polity score is constant during the time of the observations, this information will not be used to calculate the polity coefficient. Looking at the histogram of the polity scores of the observations that are included in model 11, it becomes clear that the majority of these polity scores lies between 6 and 9 . This means that the coefficient of polity in model 11 is mainly drawn from polity scores lying between 6 and 9 . As can be seen from figure 3, in the area between polity score 6 and 9, the non-communist results of model 5 and model 11 are similar, but the results for the (post)communist countries of model 5 and 11 are not similar. Even though the slopes of model 5 (for non-communist countries) and model 11 are not entirely the same, one can say that the results are not contradicting each other as one might think first. Figure 3 also replicates the results from figure 2. A country that has a high level of tax revenue has, ceteris paribus, a decreasing level of inequality when democracy increases. A country that has a low level of tax revenue has, ceteris paribus, an increasing level of inequality. What might be explaining the decreasing level of inequality at the far right of the red curve is that when a country becomes almost fully democratic, the effect of a high tax revenue takes over the effect of democratization and therefore leads to falling levels of inequality. However, the fact that both the coefficients of tax and the interaction term between tax and polity are insignificant in model 5 makes that it is not entirely sure whether this reasoning is fully correct.

As a robustness check, model 5 has been used to see whether any lagged polity variable has an effect on inequality. This is also to control for the endogeneity, or reversed causality, what might be the case between democracy and inequality. However, it is upfront hard to think of a reasonable lagged length. Running model 5 with all four terms that consist of the polity variable and replacing them with the same lagged polity variable for each a lagged length 1 through 14 gives the result that the coefficient on the regular polity variable is the most robust. Replacing polity with polity (-1), polity (-2), etc., does change the size of this coefficient but not its sign and in many cases this coefficient is at least significant at the 10 percent level. This robustness does not hold for the other three variables which include the polity variable.

Two main conclusions come from this analysis: First, it seems to be that there is, at least between polity scores -10 and 8 a positive relationship between inequality and democracy for non-communist countries. However, two observations are less clear. On the 
one hand, it is less clear whether inequality will decrease once a country moves beyond polity score of 8 . If this is the case, the decrease is only very small as can be seen from the red curve in figure 5 . The previous paragraph has given a tentative argument that could explain this result. On the other hand, it is less clear whether inequality increases with the same speed, irrespective of how autocratic a country is or whether an increase in democracy in a very autocratic country leads to a higher increase in inequality than the same increase in democracy for a more democratic country. Second, for (post)communist countries, the relationship is different. The increase in inequality when an autocratic country becomes more democratic is less steep than for non-communist countries and second, inequality starts to fall much earlier and much more when a (post)communist country moves beyond a polity score of 1 .

\subsection{Executive recruitment, independency of authority, and political competition}

The process of democratization entails many changes. Among them are changes of how executives are recruited, changes in the independence of political leaders, and often the amount of political competition and opposition (Gurr, Jaggers, \& Marshall, 2010). Therefore, it might be informative to look not only into the broad process of democratization, rather to these individual processes separately to get more information about what exactly drives the results of section 4.1 and 4.2. As was explained in section 3, the data set of the polity score by Gurr and Marshall (2012) uses these three categories of democratization to calculate the overall polity score. In this section and table 3, the same regressions as in table 2 will be run, but with executive recruitment (exrec), independence of executive authority (xconst), and political competition and opposition (polcomp) as the main independent variables of interest. Executive authority takes on a number between 1 and 8; independence of executive authority takes on a number between 1 and 7; and political competition takes on a number between 1 and 10. In all three cases, the higher the number the more democratic the country is (Gurr, Jaggers, \& Marshall, 2010). Since in section 4.2 it was concluded that a no-effects regression and a fixed effects regression produce similar results, this section will make use only of no-effects regressions.

Table 3 shows models 14 through 17 which are all no-effects PLS regressions. The $p$-values are calculated using White period standard errors. Model 14 repeates model 5 using the three democratization processes instead of the polity score. The coefficient of executive recruitment is negative and significant at the 1 percent level. This means that when the process of executive recruitment becomes more democratic, inequality goes down. The coefficient of political competition is positive and significant at the 5 
percent level, but its square stays insignificant. The coefficients of the independence of executive authority show an inverted $U$-shape which is highly significant. The effects of the communist variables is that (post)communist countries have on average an inequality level which is 26.539 higher when the polity score is o, but if the executive authority gets more independent the increase in inequality is smaller for (post)communist countries compared to non-communist countries. Models 15 and 16 control for market economies, similar to models 6 and 7. However, which was also the case in models 6 and 7, the coefficients of OECD, trade, and FDI are insignicant and additionally, the adjusted $\mathrm{R}^{2}$ does not increase when these variables are added. So far, it seems that model 14 explains inequality best. Yet, polcomp ${ }^{2}$ is insignificant and therefore adds no information to this regression, but only changes the coefficient of political comptition itself. Model 17 replicates model 14 , deleting polcomp ${ }^{2}$ from the regression and this is the final model when the democratization process is split in three individual processes. The coefficient of political competition becomes more significant, but stays positive.

In sum, the democratization of executive recruitment leads to a linear, negative effect on inequality, while the degree of political competition leads to a linear, positive effect on inequality. However, the main effect of democratization on inequality comes from the inverted $U$-shaped relationship between independence of executive authority and inequality. The maximum level of inequality is achieved when independence of executive authority is around 6, which means almost full independence. Therefore, for most of the increases in independence, inequality is on the rise. A country with higher tax revenues compared with a country with lower tax revenues will experience less inequality decreases when its executive recruitment process becomes more democratic. Furthermore, this country will experience less increases in its inequality level when its political competition increases. The interaction between independence of executive authority and tax revenue has no influence on inequality, but the interaction between independence of executive authority and communist has an influence on inequality. If a (post)communist country experiences an increase in the independence of executive authority, inequality increases to a lesser degree than for a non-communist country. Additionally, the level of inequality starts to fall sooner for a (post)communist country as compared with a non-communist country when the degree of independence increases. This can be seen from figure 4 which plots the development of inequality against independence of executive authority for both a (post)communist and non-communist country. 


\subsection{Redistribution}

So far, this paper analyzed the effect of democratization on income inequality. However, the level of inequality does not necessary say anything about the level of redistribution. As has been concluded previously, inequality is positively affected by democratization. However, is the amount a government redistributes also affected by the political regime? Lee (2005) finds an inverted U-shaped relatioship between inequality and the public sector. However, the empirical relationship between inequality and taxation is weak (Boix, 2003, p. 202). It therefore cannot be said that the same relationship holds between redistribution and regime type as it does between inequality and regime type. Boix (2003) finds empirical evidence that the public sector, and therefore the amount of redistribution, is affected by the type of regime in place. Authorian regimes often have a much smaller public sector when compared with a democratic regime, however, this does not say anything directly whether authoritarian regimes redistribute differently than democratic regimes.

To answer this question, Gini data of gross and disposable income are taken from the world income inequality database (UNU-WIDER, 2008b) and substracted from each other. This gives a dataset of 112 observation from between 1980 and 2003 that represent the difference in Gini between a gross and disposable income measure. Table 4 shows the results when polity is regressed on this difference in Gini indexes, called redistribution, and several other control variables. Gini is a control variable, because the level of inequality might influence the degree to which income is redistributed. Log(GNI) controls for the level of development within a country. According to Boix (2003, p. 181), economic development can be positively related with the public sector and therefore with the amount of redistribution. Voter turnout might also influences the amount of redistribution. In Boix's (2003) theory on democracy and the public sector, he assumes that when the voter turnout goes down, mostly low-income citizens surrender from voting rather than high-income citizens. Therefore, the median voter's income increases. Since, in theory, the median voter's income is negatively related with the amount of redistribution, a lower voter turnout will lead to lower redistribution. Boix (2003, p. 187) finds that there is a difference in how voter turnout effects redistribution when a developed country is compared with an underdeveloped country. Therefore, an interaction term between voter turnout and economic development is added to the regression. If the population is relatively old, there are more redistributive pressures and therefore it is expected that dependency is positively related with redistribution (Boix, 2003). This time, only the porportion of people above the age of 65 are used to calculate dependency. Further, an interaction term between dependency and polity is added. It is expected that a democracy is better able to meet the demands of its citizens and therefore better able to react to the 
demands of the older population in contrast with an autocratic government (Boix, 2003, p. 181). Additionally, trade and agriculture are added as well. Trade has been shown to lead to a larger public sector (Boix, 2003) and the percentage of workforce working in agriculture is added because according to Boix (2003, p. 175) pressures to redistribute in farmer economies is small. The polity and Gini variables are taken from the primary dataset as described in section 4. The logarithm of GNI, dependency of old population, trade, and the share of population working in agriculture are taken from the World dataBank (World Bank, n.d.). Voter turnout, lagged with one year, is taken from the International Institute for Democracy and Electoral Assistence (IDEA, n.d.). The regression in table 4 is a no-effect regression and the $p$-values are calculated using White period standard errors.

Table 4 gives the result of this regression. The coefficient on polity is negative and significant at the 1 percent level. The coefficient of polity ${ }^{2}$ is insignificant. Therefore, it can be said that an increase in democracy leads to a lower level of redistribution. The coefficient of Gini is positive and significant at the 10 percent level. The higher inequality is the more income will be redistributed. This result fits the expectations. The coefficients on economic development, voter turnout, and their interaction are insignificant. However, they are jointly significant $(\mathrm{F}[3,100]=5.848)$. The coefficient of dependency is, against the expectations, negative and highly significant. Yet, the interaction term between dependency and polity is positive. The relationship between redistribution and polity for both a country with a large older population and a country with a small older population is given in figure 5 . In this regression, trade leads to a slightly lower amount of redistribution and agriculture to more redistribution, both results are different than expected. The observations used to construct table 4 are mainly from developing countries. Therefore, it seems that democracy not only leads to more inequality, it also leads to less redistribution, at least when looking at developed countries. 


\section{Conclusion}

Theoretical arguments fail to give a direction of the causality between income inequality and democracy. On the one hand, theorists believe that democracy leads to more inequality because there should be less intervention of the government in a democratic regime. On the other hand, other theorists argue that in a democratic regime there is a certain degree of ethical values which creates a demand for at least some redistribution. Since theoretical arguments fail to establish an answer, one needs to look at empirical analyses. This paper has made several improvements on the existing empirical literature that links inequality with democratization.

As a proxy for inequality, this paper uses the Gini index and as a proxy for democratization it uses the polity score. The standard no-effects regressions revealed that there is an inverted U-shaped relationship, similar to the one found by Simpson (1990). However, the fixed effects regression states income inequality increases when a country becomes more democratic. Although these conclusions seem to contradict each other, a better look at the data revealed that they are not contradicting each other. Even though they do not state the exact same result, one can come to two main conclusions from this analysis: first, it seems to be that there is, at least between polity scores -10 and 8 a positive relationship between inequality and democracy for non-communist countries. However, two observations are less clear. On the one hand, it is less clear whether inequality will decrease once a country moves beyond polity score of 8 . Section 4.2 has given a tentative argument that could explain this result. On the other hand, it is less clear whether inequality increases with the same speed, irrespective of how autocratic a country is or whether an increase in democracy in a very autocratic country leads to a higher increase in inequality than the same increase in democracy for a more democratic country. Second, for (post)communist countries, the relationship is different. The increase in inequality when an autocratic country becomes more democratic is less steep than for non-communist countries and second, inequality starts to fall much earlier and much more when a (post)communist country moves beyond a polity score of 1 .

As was described in section 4.3, democratization entails many processes. Gurr, Jaggers, and Marshall (2010) recognize this and find three individual processes in democratization: democratization of the recruitment of the executive, the degree of independence of the executive authority, and the degree of political competition and opposition. Using these three variables gives three effects of democratization on inequality. The democratization of executive recruitment leads to a linear, negative effect on inequality, while the degree of political competition leads to a linear, positive effect on inequality. The main effect of democratization on inequality comes from the inverted U-shaped relationship between 
independence of executive authority and inequality. The maximum level of inequality is achieved when there is almost full independence. If a (post)communist country experiences an increase in the independence of executive authority, inequality increases to a lesser degree than for a non-communist country. Additionally, the level of inequality starts to fall sooner for a (post)communist country as compared with a non-communist country when the degree of independence increases. In section 4.4 it was looked how democratization leads to a different degree of redistribution. Since the level of inequality does not say directly something about the level of redistribution, a separate analysis needs to be done. This analysis follows mainly the analysis of Boix (2003). This paper uses the difference between a Gini index calculated from a gross income measure and a disposable income measure. It is concluded that democracy not only leads to more inequality, it also leads to less redistribution.

Even though this paper has found a positive relationship between inequality and democracy, it is not suggesting that there is no reversed causality. This reversed causality that inequality leads to different regime types is very well analyzed by Boix (2003) and others. It might be possible that there is a vicious relationship between inequality and democracy: on the one hand, democracy affects inequality, and on the other hand, inequality affects democracy.

Since democracy leads to more inequality and less redistribution, this paper is not to suggest that an autocratic regime is preferred to a democratic regime. However, it is important that the processes within democratization that cause this increase in inequality will be discovered. This analysis has made some first steps in finding out what really drives inequality. First, it was thought that the market economy, which is positive correlated with democracy, might increase inequality. However, including variables to control for this did not reduce the effect of regime type on inequality. Second, there was extensively controlled for that (post)communistic countries could have a different relationship between inequality and democratization. This analysis revealed that there is indeed a different relationship, but that the positive effect of democracy on inequality is independent of communism. Third, regressing the three separate processes of democratization shows that both independence of the executive authority and the degree of political competition have a positive effect on inequality. Only the democratization of the recruitment process of the executive has a decreasing effect on inequality. It is suggested that further research will look more into the causal relationship between inequality and democracy to find out what exactly within the process of democracy drives inequality up. Once this answer is found, governmental policies and programs need to be adjusted to fight this increase in inequality to make the world a more stable place, both economically and politically. 


\section{Appendix}

Table 1. Unstandardized coefficient from the PLS regression of income inequality (Gini) on selected independent variables (1990-2006)

\begin{tabular}{|c|c|c|c|c|c|c|c|}
\hline & {$[1]$} & [2] & [3] & {$[4]$} & [5] & [6] & [7] \\
\hline Constant & $20.362^{* * 8}$ & $29.904^{* * 8}$ & $-62.408^{*}$ & -15.436 & -36.709 & -37.205 & -34.957 \\
\hline Polity & -0.213 & $0.536^{* * *}$ & $0.555 *$ & $0.646^{*}$ & $1.950^{* * *}$ & $2.009 * * *$ & $1.983^{* * *}$ \\
\hline Polity ${ }^{2}$ & & $-0.182^{* * *}$ & $-0.098 * 8$ & -0.045 & $-0.125^{* * *}$ & $-0.128 * 8 *$ & $-0.124^{* * *}$ \\
\hline $\log (\mathrm{GNI})$ & & & $21.994 * * *$ & 6.311 & $14.791^{* * *}$ & $15.085^{* * *}$ & $14.536^{* * *}$ \\
\hline $\log (\mathrm{GNI})^{2}$ & & & $-1.200 * * *$ & -0.351 & $-0.977^{* * *}$ & $-1.000^{* * *}$ & $-0.961 * * *$ \\
\hline Log(energy) & & & $-4.452 * * *$ & -1.652 & -1.348 & -1.453 & -1.401 \\
\hline Education & & & -0.133 & 0.034 & -0.074 & -0.081 & -0.076 \\
\hline Education $^{2}$ & & & 0.000 & 0.000 & 0.000 & 0.000 & 0.000 \\
\hline Dependency & & & $0.289 * *$ & 0.032 & -0.035 & -0.039 & -0.038 \\
\hline Agriculture & & & $0.160^{*}$ & $0.208^{* * 8}$ & $0.147^{* *}$ & $0.146^{* *}$ & $0.146^{* *}$ \\
\hline Service & & & 0.125 & 0.062 & 0.062 & 0.063 & 0.062 \\
\hline Tax & & & -0.104 & 0.285 & 0.161 & 0.176 & 0.180 \\
\hline Tax*Polity & & & -0.013 & $-0.035 *$ & -0.024 & -0.024 & -0.026 \\
\hline Latin America & & & & $16.878^{* * *}$ & $12.853^{* * *}$ & $13.077^{* * *}$ & $12.861^{* * *}$ \\
\hline Africa & & & & $13.463^{888}$ & $11.932^{* * *}$ & 12.039888 & $11.907^{* * *}$ \\
\hline Asia & & & & 1.933 & $-2.531 *$ & $-2.539 *$ & -2.359 \\
\hline Communist & & & & & $8.298^{* *}$ & $9.001 * 8$ & $8.324^{* *}$ \\
\hline Communist ${ }^{*}$ Polity & & & & & $-1.700^{* * *}$ & $-1.757^{* * *}$ & $-1.691^{* * *}$ \\
\hline $\mathrm{OECD}$ & & & & & & 0.680 & \\
\hline Trade & & & & & & & -0.004 \\
\hline FDI & & & & & & & 0.008 \\
\hline Urban & $8.995^{* 8 *}$ & $6.278 * * *$ & -3.391 & $-5.801^{8 *}$ & $-7.084^{* * 8}$ & $-6.994^{* 8 *}$ & $-7.220 * 8 *$ \\
\hline Gross & $9.453 * * *$ & $10.089 * * *$ & $20.443^{* * *}$ & $21.447^{* * *}$ & $23.560^{* * *}$ & $23.711^{* * *}$ & $23.608^{* * *}$ \\
\hline Disposable & $-7.423 * 8$ & -5.435 & $13.439 * * *$ & $14.665^{* * *}$ & $16.309 * * *$ & $16.231^{* * *}$ & $16.500^{* * *}$ \\
\hline Consumption & $-9.311^{* 8}$ & $-12.290^{* * *}$ & $9.997 * *$ & $9.229 * 8$ & $6.784^{* *}$ & $6.749 * 8$ & $7.020 * *$ \\
\hline Earnings & 3.259 & -0.144 & $11.180 * * *$ & $7.726^{* *}$ & $7.507^{* * *}$ & $7.575^{* * *}$ & $7.510 * * *$ \\
\hline Shareuhousehold & $19.659 * 8 *$ & $16.814^{* * *}$ & $10.610^{* * *}$ & $8.499 \$ 8 *$ & $10.460^{* * *}$ & $10.658^{* 8 *}$ & $10.270^{* 8 *}$ \\
\hline Uofanalaperson & $5.193^{* * *}$ & $4.607 * * *$ & -0.399 & -1.804 & -2.596 & -2.581 & -2.617 \\
\hline $\mathrm{R}^{2}$ & 0.376 & 0.487 & 0.777 & 0.848 & 0.882 & 0.882 & 0.882 \\
\hline Adjusted $\mathrm{R}^{2}$ & 0.370 & 0.482 & 0.767 & 0.840 & 0.875 & 0.875 & 0.874 \\
\hline Number of observations & 924 & 924 & 434 & 434 & 434 & 434 & 427 \\
\hline Cross-sections included & 104 & 104 & 56 & 56 & 56 & 56 & 56 \\
\hline
\end{tabular}

Note: $p$-values calculated using White period standard errors and covariance (d.f. corrected)

${ }^{*} p<.10,{ }^{* *} p<.05,{ }^{* * *} p<.01$ (two-tailed test)

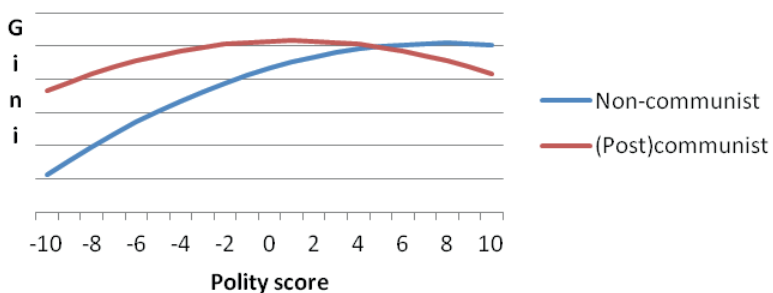

Figure 1 The path of inequality as an interaction of democracy and communism, model 5 
Table 2. Unstandardized coefficient from the PLS fixed effect regression of income inequality (Gini) on selected independent variables (1990-2006)

\begin{tabular}{|c|c|c|c|c|c|c|}
\hline & [8] & [9] & [10] & [11] & [12] & [13] \\
\hline Constant & $32.211 * * *$ & $32.044 * * *$ & -58.804 & -56.768 & -64.637 & -63.661 \\
\hline Polity & 0.155 & 0.142 & $0.890 * * *$ & $1.126^{* * *}$ & $1.158 * * *$ & $1.051 * * *$ \\
\hline Polity $^{2}$ & & 0.003 & 0.037 & & & \\
\hline $\log (\mathrm{GNI})$ & & & -4.219 & -4.382 & -2.818 & -3.291 \\
\hline $\log (\mathrm{GNI})^{2}$ & & & 0.802 & 0.837 & 0.746 & 0.772 \\
\hline Log(energy) & & & 3.321 & 2.983 & 3.182 & 3.176 \\
\hline Education & & & 0.010 & 0.014 & -0.001 & 0.028 \\
\hline Education $^{2}$ & & & 0.000 & 0.000 & 0.000 & 0.000 \\
\hline Dependency & & & $0.204 *$ & $0.219 *$ & $0.219 *$ & 0.204 \\
\hline Agriculture & & & -0.009 & -0.016 & -0.019 & -0.027 \\
\hline Service & & & 0.079 & 0.075 & 0.083 & 0.084 \\
\hline $\operatorname{Tax}$ & & & $0.723 * * *$ & $0.757 * * *$ & $0.690 * * *$ & $0.650 * * *$ \\
\hline Tax*Polity & & & $-0.063 * * *$ & $-0.066 * * *$ & $-0.059 * * *$ & $-0.055 * * *$ \\
\hline Communist*Polity & & & & & -0.267 & -0.271 \\
\hline Trade & & & & & & 0.018 \\
\hline FDI & & & & & & 0.000 \\
\hline Urban & $-6.906 * *$ & $-6.883 * *$ & $-13.216 * * *$ & $-13.667 * * *$ & $-13.725 * * *$ & $-13.619 * * *$ \\
\hline Gross & $7.937 * * *$ & $7.950 * *$ & $13.125 * * *$ & $12.602 * * *$ & $13.014 * * *$ & $13.367 * * *$ \\
\hline Disposable & $7.033 * *$ & $7.042 * *$ & $17.231 * * *$ & $16.790 * * *$ & $17.140 * * *$ & $17.504 * * *$ \\
\hline Consumption & 2.086 & 2.079 & $6.525 *$ & $5.938 *$ & $6.134 *$ & $6.790 *$ \\
\hline Earnings & -0.108 & -0.107 & 4.483 & 4.434 & 4.511 & 4.616 \\
\hline Shareuhousehold & -0.191 & -0.184 & -0.340 & -0.367 & -0.238 & -0.260 \\
\hline Uofanalaperson & -1.288 & -1.278 & -3.080 & -3.133 & -3.091 & -3.066 \\
\hline $\mathrm{R}^{2}$ & 0.937 & 0.937 & 0.967 & 0.966 & 0.967 & 0.967 \\
\hline Adjusted $\mathrm{R}^{2}$ & 0.927 & 0.927 & 0.958 & 0.958 & 0.958 & 0.957 \\
\hline Number of observations & 924 & 924 & 434 & 434 & 434 & 427 \\
\hline Cross-sections included & 104 & 104 & 56 & 56 & 56 & 56 \\
\hline
\end{tabular}

Note: $p$-values calculated using White period standard errors and covariance (d.f. corrected) Cross-section fixed and period fixed effect regression

${ }^{*} p<.10,{ }^{* *} p<.05,{ }^{* * *} p<.01$ (two-tailed test)

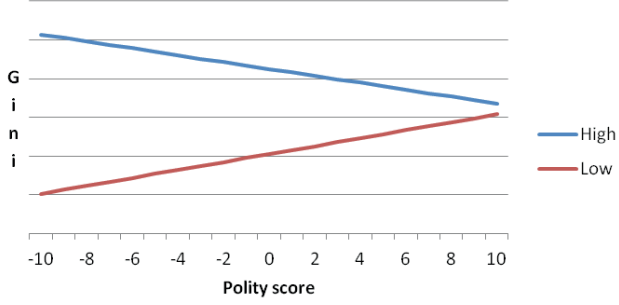

Figure 2 The path of inequality as an interaction of democracy and tax revenue, model 11.

Note: high tax revenue is calculated as the average of the sample 1990-2006 (16.543) plus 1 SD (7.261). Low tax revenue is calculated as the average minus 1 SD. A country comparable to this high tax revenue country is Australia around 2002. A country comparable to this low tax revenue country is United States and Tajikistan in 2003. 
G

i

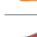

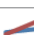

$\begin{array}{lllllllllllllllllllll}-10 & -9 & -8 & -7 & -6 & -5 & -4 & -3 & -2 & -1 & 0 & 1 & 2 & 3 & 4 & 5 & 6 & 7 & 8 & 9 & 10\end{array}$

Polity score
- Fixed effects model 11

No-effects model 5 , Non-communist

No-effects model 5 , Communist

High

Low

Figure 3 The path of inequality as an interaction of democracy, communism, and tax revenue, models 5 an 11

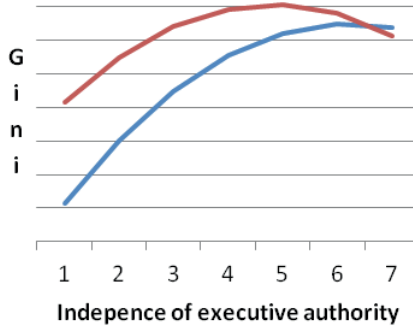

Figure 4 The path of inequality as an interaction between independence of executive authority and communism 
Table 3. Unstandardized coefficients from the PLS regression of income inequality (Gini) on selected independent variables (1990-2006)

\begin{tabular}{|c|c|c|c|c|}
\hline & [14] & [15] & [16] & [17] \\
\hline Constant & $-49.708^{*}$ & $-50.123^{* *}$ & $-47.318^{*}$ & $-45.706^{*}$ \\
\hline Exrec & $-5.545 * *$ & $-5.533 * *$ & $-5.664 * *$ & $-5.407 * * *$ \\
\hline Exrec $^{2}$ & & & & \\
\hline Xconst & $11.671^{* *}$ & $11.656^{* *}$ & $11.620^{* *}$ & $12.332 * * *$ \\
\hline Xconst ${ }^{2}$ & $-0.900 * *$ & $-0.898 * *$ & $-0.892 * *$ & $-0.995 * * *$ \\
\hline Polcomp & $5.992 * *$ & $6.048 * *$ & $6.178 * *$ & $3.623 * * *$ \\
\hline Polcomp ${ }^{2}$ & -0.170 & -0.173 & -0.160 & \\
\hline $\log (\mathrm{GNI})$ & $13.627 * *$ & $13.694 * *$ & $13.240^{* *}$ & $13.273 * * *$ \\
\hline $\log (\mathrm{GNI})^{2}$ & $-0.877 * *$ & $-0.882 * *$ & $-0.849 * *$ & $-0.873^{* * *}$ \\
\hline Log(energy) & $-2.806^{* *}$ & $-2.827 * *$ & $-2.994 * *$ & $-2.607 * *$ \\
\hline Education & -0.134 & -0.136 & -0.152 & -0.109 \\
\hline Education ${ }^{2}$ & 0.001 & 0.001 & 0.001 & 0.000 \\
\hline Dependency & -0.043 & -0.044 & -0.045 & -0.035 \\
\hline Agriculture & $0.128 *$ & $0.128 *$ & $0.125^{*}$ & $0.139 * *$ \\
\hline Service & 0.067 & 0.067 & 0.068 & 0.067 \\
\hline Tax & -0.323 & -0.323 & -0.247 & -0.064 \\
\hline Tax*Exrec & $0.438 * *$ & $0.439 * *$ & $0.448 * *$ & $0.418 * * *$ \\
\hline Tax*Xconst & -0.090 & -0.091 & -0.087 & -0.059 \\
\hline Tax*Polcomp & $-0.269 * *$ & $-0.268 * *$ & $-0.286 * *$ & $-0.300 * * *$ \\
\hline Latin America & $11.844^{* *}$ & $11.892 * *$ & $11.876 * *$ & $11.708 * * *$ \\
\hline Africa & $11.151 * *$ & $11.175 * *$ & $11.030^{* *}$ & $10.586 * * *$ \\
\hline Asia & $-4.092 * *$ & $-4.078 * *$ & $-3.578 * *$ & $-4.545 * * *$ \\
\hline Communist & $26.539 * *$ & $26.956 * *$ & $26.775 * *$ & $17.831 * * *$ \\
\hline Communist ${ }^{*}$ Exrec & -1.622 & -1.644 & -1.470 & -0.999 \\
\hline Communist ${ }^{*} \mathrm{X}$ const & $-2.708 *$ & $-2.711 *$ & $-2.756 *$ & $-2.719 *$ \\
\hline Communist*Polcomp & -0.277 & -0.296 & -0.358 & 0.105 \\
\hline $\mathrm{OECD}$ & & 0.130 & & \\
\hline Trade & & & -0.009 & \\
\hline FDI & & & 0.027 & \\
\hline Urban & $-6.711^{* *}$ & $-6.698 * *$ & $-7.096 * *$ & $-6.341 * * *$ \\
\hline Gross & $24.632 * *$ & $24.652 * *$ & $24.863 * *$ & $25.449 * * *$ \\
\hline Disposable & $18.299 * *$ & $18.280^{* *}$ & $18.849 * *$ & $19.282 * * *$ \\
\hline Consumption & $6.055 *$ & $6.040 *$ & $6.536 *$ & $7.237 * *$ \\
\hline Earnings & $9.867 * *$ & $9.871 * *$ & $10.084 * *$ & $10.709 * * *$ \\
\hline Shareuhousehold & $10.828 * *$ & $10.856 * *$ & $10.595 * *$ & $11.077 * * *$ \\
\hline Uofanalaperson & $-2.901 *$ & $-2.898 *$ & $-2.912 *$ & -2.881 \\
\hline $\mathrm{R}^{2}$ & 0.891 & 0.891 & 0.891 & 0.890 \\
\hline Adjusted $\mathrm{R}^{2}$ & 0.882 & 0.882 & 0.882 & 0.882 \\
\hline Number of observation & 433 & 433 & 426 & 433 \\
\hline Cross-sections includer & 56 & 56 & 56 & 56 \\
\hline
\end{tabular}

Note: $b$-values are calculated using White veriod standard errors and covariances

${ }^{*} b<.10{ }^{* *} p<.05 . * * * b<.01$ (two-tailed test)

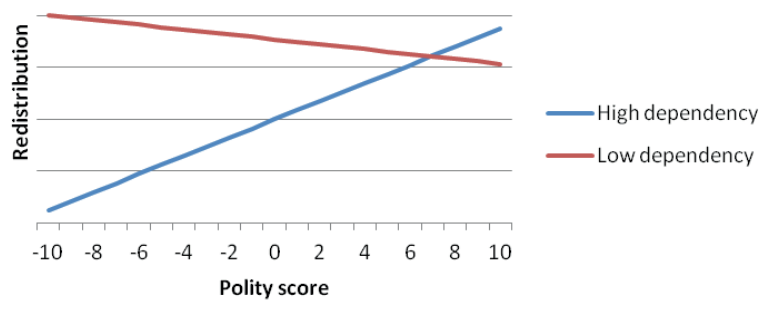

Figure 5 Path of redistribution as an interaction between democracy and dependency ratio Note: high dependency is calculated as the average of the sample 1980-2003 (10.693) plus 1 SD (6.094). Low dependency is calculated as the average minus 1 SD. A country comparable to this high dependency ratio is Australia around 1988. A country comparable to this low dependency ratio is Paraguay in 1980. 
Table 4. Unstandardized coefficient from the PLS regression of Redistribution on selected independent variables (1980-2003)

\begin{tabular}{|c|c|}
\hline Constant & 21.282 \\
\hline Polity & $-1.316 * * *$ \\
\hline Polity $^{2}$ & 0.000 \\
\hline Gini & $0.097 *$ \\
\hline $\log (\mathrm{GNI})$ & -2.887 \\
\hline Voter turnout & -0.003 \\
\hline Voter turnout $* \log (\mathrm{GNI})$ & 0.001 \\
\hline Dependency, old & $-1.270 * * *$ \\
\hline Dependency, old * polity & $0.183 * * *$ \\
\hline Trade & $-0.058 * * *$ \\
\hline Agriculture & $0.389 * * *$ \\
\hline $\mathrm{R}^{2}$ & 0.627 \\
\hline Adjusted $\mathrm{R}^{2}$ & 0.586 \\
\hline Number of observations & 112 \\
\hline Cross-sections included & 17 \\
\hline
\end{tabular}

Note: $p$-values calculated using White period standard errors and covariance (d.f. corrected) ${ }^{*} p<.10,{ }^{* *} p<.05,{ }^{* * *} p<.01$ (two-tailed test) 


\section{References}

Bermeo, N. (2012). Does electoral democracy boost economic equality? In F. Fukuyama, L. Diamond, \& M. Plattner, Poverty, inequality and democracy (pp. 14-28). Baltimore, MD: The Johns Hopkins University Press.

Boix, C. (2003). Democracy and redistribution. New York, NY: Cambridge University Press.

Brown, A. (2009). The rise and fall of communism. New York, NY: Harper Collins.

Dutt, P., \& Mitra, D. (2008). Inequality and the instability of polity and policy. The Economic Journal, 118, 1285-1314.

Fukuyama, F. (2012a). Dealing with inequality. In F. Fukuyama, L. Diamond, \& M. Plattner, Poverty, inequality, and democracy (pp.3-13). Baltimore, MD:The Johns Hopkins University Press.

Gradstein, M., \& Milanovic, B. (2004). Does liberté = egalité? A survey of the empirical links between democracy and inequality with some evidence on the transition economies. Journal of Economic Surveys, 18(4), 515-537.

Gurr, T., \& Marshall, M. (2012). Polity IV Project: Political regime characteristics and transitions, 1800-2012. Retrieved November 12, 2012, from Systemic Peace: http://www.systemicpeace.org/polity/polity4.htm

Gurr, T., Jaggers, K., \& Marshall, M. (2010). Polity IV Project: Political regime characteristics and transitions, 180-2010: Dataset users' manual. Retrieved November 12, 2012, from Systemic Peace: http://www.systemicpeace.org/polity/polity4.htm

IDEA. (n.d.). Voter turnout database. Retrieved June 25, 2013, from IDEA: http://www.idea.int/vt/viewdata.cfm

Kapstein, E., \& Converse, N. (2012). Why democracies fail. In F. Fukuyama, L. Diamond, \& M. Plattner, Poverty, inequality and democracy (pp. 29-40). Baltimore, MD: The Johns Hopkins University Press.

Kennedy, P. (2008). A guide to econometrics ( $6^{\text {th }}$ Ed.). Malden, MA: Blackwell.

Lee, C. (2005). Income inequality, democracy, and public sector size. American Sociological Review, 70, 158-181.

Lewis, P. (2012). Growth without prosperity in Africa. In F. Fukuyama, L. Diamond, \& M. Plattner, Poverty, inequality and democracy (pp. 123-137). Baltimore, MD: The Johns Hopkins University Press.

Muller, E. (1988). Democracy, economic development, and income inequality. American Sociological Review, 53, 50-68.

Orenstein, M. (2012). Postcommunist welfare states. In F. Fukuyama, L. Diamond, \& M. Plattner, Poverty, inequality and democracy (pp. 76-9o). Baltimore, MD: The Johns Hopkins University Press. 
Perkins, D., Radelet, S., \& Lindauer, D. (2006). Economics of development ( $6^{\text {th }}$ Ed.). New York, NY: W. W. Norton \& Company.

Plattner, M. (2012). Introduction. In F. Fukuyama, L. Diamond, \& M. Plattner, Poverty, inequality and democracy (pp. xi-xvii). Baltimore, MD: The Johns Hopkins University Press.

Simpson, M. (1990). Political rights and income inequality: a cross-national test. American Sociological Review, 55, 682-693.

Toledo, A. (2012). Latin America: democracy with development. In F. Fukuyama, L. Diamond, \& M. Plattner, Poverty, inequality and democracy (pp. 41-47). Baltimore, MD: The Johns Hopkins University Press.

UNU-WIDER. (2008 (a)). World Income Inequality Database User Guide and Data Sources. Retrieved November 4, 2012, from UNU-WIDER :

http://website1.wider.unu.edu/wiid/wiid-documentation1.php

UNU-WIDER. (2008(b)). World Income Inequality Database V2.0c May 2008. Retrieved November 4, 2012, from UNU-WIDER:

http://www.wider.unu.edu/research/Database/en_GB/wiid/

Wooldridge, J. (2009). Introductory econometrics: a modern approach ( $4^{\text {th }}$ Ed.). Stamford, CT: South-Western Cengage Learing.

World Bank. (n.d.). World Development Indicators. Retrieved April 23, 2013, from World dataBank: http://databank.worldbank.org/data/home.aspx 